\title{
Duration of co-feeding on the Nishikigoi Cyprinus carpio larvae during weaning from live to inert food in an indoor system
}

\author{
Paulo José Fosse ${ }^{1}$ Douglas da Cruz Mattos $^{2}$ Leonardo Demier Cardoso ${ }^{1}$ \\ Marcella Costa Radael ${ }^{* *}$ João Carlos Fosse Filho ${ }^{4}$ Manuel Vazquez Vidal Júnior ${ }^{4}$
}

\author{
${ }^{1}$ Instituto Federal de Educação, Ciência e Tecnologia do Espírito Santo, Campus de Alegre, Alegre, ES, Brasil. \\ ${ }^{2}$ Instituto Federal de Educação, Ciência e Tecnologia do Espírito Santo, Campus de Piúma, Piúma, ES, Brasil. \\ ${ }^{3}$ Universidade Federal do Oeste do Pará, Campus Universitário de Monte Alegre, Travessa Major Francisco Mariano, Cidade Alta, 68220-000, \\ Monte Alegre, PA, Brasil. E-mail: marcellacradael@gmail.com. *Corresponding author. \\ ${ }^{4}$ Centro de Ciências e Tecnologias Agropecuárias, Universidade Estadual do Norte Fluminense Darcy Ribeiro, Campos dos Goytacazes, RJ, Brasil.
}

\begin{abstract}
This study aimed to evaluate the effects of the co-feeding period (C) on the survival and growth of larvae of nishikigoi Cyprinus carpio, during the weaning period from live to inert food. A total of 1680 larvae with initial weight of $1.33 \pm 0.12 \mathrm{mg}$ and initial length of 6.0 $\pm 0.33 \mathrm{~mm}$ were used. The inert diet used was a commercial ration with $55 \%$ crude protein and the live food was the newly hatched nauplii of Artemia franciscana. The experiment was conducted following a completely randomized design with six treatments and four replications. Treatments constituted of: a) $L F=$ supply of live food throughout the experimental period; b) C4 $=6$ days of live food +4 days of co-feeding (inert diet and live food) +16 days of inert diet; $c$ ) $C 8=6$ days of live food +8 days of co-feeding +12 days of inert diet; d) $C 12=6$ days of live food +12 days of co-feeding +8 days of inert diet; e) IF = supply with inert diet throughout the experimental period; and f) $F=$ fasting. Our results showed that the co-feeding period influences the survival and growth of the larvae. Survival in the treatment with the longest cofeeding period showed an improvement of over $70 \%$ when compared to the shortest period. Further, we noted a doubling of the juvenile weight after 26 days of age. There was a quadratic effect for all parameters, with maximum points ranging between 19.4 and 22.6 days of supply of live food. We concluded that the supply of commercial feed as exclusive food is unworkable in nishikigoi larviculture.

Key words: feeding, feed Intake, larval fish, ornamental fish.
\end{abstract}

Período de co-alimentação na transição alimentar de larvas de Nishikigoi Cyprinus carpio em sistema "in door"

RESUMO: Com o objetivo de avaliar os efeitos do período de co-alimentação $(C)$ na sobrevivência e crescimento de larvas de nishikigoi Cyprinus carpio, durante o periodo de transição de alimentos vivos (AV) para dieta inerte (DI), foram utilizados um total de 1680 larvas com peso inicial de 1,33 \pm 0,12mg e comprimento inicial de 6,0 \pm 0,33mm. Para a dieta inerte foi utilizada uma ração comercial com 55\% de proteina bruta e como alimento vivo, nauplios recém eclodidos de Artemia franciscana. O experimento foi conduzido em delineamento inteiramente casualizado com seis tratamentos e quatro repetições. Os tratamentos foram constituidos por: LF = suprimento de alimento vivo ao longo de todo período experimental; $\mathrm{C} 4=6$ dias de alimento vivo +4 dias de co-alimentação (dieta inerte e alimento vivo) +16 dias de dieta inerte; $C 8=6$ dias de alimento vivo +8 dias de co-alimentação +12 dias de dieta inerte; $C 12=6$ dias de alimento vivo +12 dias de co-alimentação +8 dias de dieta inerte; $I D=$ dieta inerte durante todo o período experimental, $J=j e j u m$. O período de co-alimentação influencia a sobrevivência e o crescimento das larvas melhorando mais de $70 \%$ a sobrevida entre os períodos de co-alimentação mais longos e curtos testados. Além disso, foi verificado um aumento de duas vezes o peso juvenil após 26 dias de idade. Houve um efeito quadrático para todos os parâmetros, com pontos máximos variando entre 19,4 e 22,6 dias de suprimento de alimentos vivos. Também é possível concluir que o fornecimento de alimentação comercial, como alimento exclusivo, é inviável na larvicultura de nishikigoi.

Palavras-chave: alimentação, ingestão alimentar, larva de peixe, peixe ornamental.

\section{INTRODUCTION}

Nishikigoi is the term used for colored carp produced for ornamental purposes, which are classified according to their racial pattern. They were developed from the color variations in the common carp Cyprinus carpio, between the $17^{\text {th }}$ and $19^{\text {th }}$ centuries, in Japan (HANIFFA et al., 2007).

The larviculture phase of this cyprinid is usually held in land ponds, in semi intensive production systems. However, keeping the larvae in an intensive system for a short period of time 
has proved more efficient than the direct storage of the larvae in the ponds, similar to that shown by JOMORI et al. (2003) in the production of juvenile pacu Piaractus mesopotamicus.

Fish larvae that are altricial have scarce reserves of yolk and do not have a fully formed and functional digestive system when exogenous feeding is initiated. It therefore, cannot efficiently exploit inert food (KOLKOVSKI, 2001), becoming dependent on living food in its initial stages of growth (CAHU \& ZAMBONINO-INFANTE, 2001; TESSER et al., 2005).

The nutritional goal to be achieved is the formulation of an inert food able to fully suppress the living food from the beginning of exogenous feeding of the larvae fish without damage to survival and growth. Despite advances in research, most studies report that; altholugh possible, it is still uneconomical to use inert food as the first exogenous feed for altricial fish larvae (TESSER et al., 2005; JOMORI et al., 2008; MENOSSI, et al., 2012). Early replacement of living food with inert food has led to a reduction in the growth and survival of larvae (JELKIĆ et al., 2012; JOMORI et al., 2008; PUELLO-CRUZ et al., 2010), compared to longer supply of living food (LOMBARDI \& GOMES, 2008).

The use of strategies to early suppress the living food, without restricting the growth and especially in the case of ornamental fish, survival is necessary, since the cost of production of fish larvae in intensive regimen increases when higher is the time of offering the living food (JOMORI et al., 2005), due to the high cost of living food compared to the cost of the inert food. Therefore, it becomes important to adopt strategies to gradually replace the living food with inert food, as well as to determine the ideal time to stop feeding living food (PORTELLA \& DABROWSKI, 2008) without loss in the growth and, especially in the case of ornamental fish, reduction in survival.

Replacement of living food with inert food can be made abruptly, completely replacing the living with inert food, or gradually, starting with a period of combined feeding, reducing the living food and gradually increasing the supply of inert food until it is the exclusive food supplied (PORTELLA et al., 2013). This combined feeding method is called co-feeding strategy, wherein growth rates may be similar or better than those achieved with the supply of Artemia alone (PERSON LE RUYET et al., 1993), helping to reduce the living food supply time and consequently, production costs (PERSON LE RUYET et al., 1993; TESSER et al., 2006; JOMORI et al., 2008; MENOSSI et al., 2012).

Zooplankton is fundamental to the initial feeding of altricial larvae. Based on this premise, the logic of the use of co-feeding is to allow the larvae to adapt to capture, ingestion, digestion, and absorption of nutrients from the inert food from an earlier stage in their lifecycle, while avoiding the low growth and high rates of mortality from starvation in an abrupt transition between the two diets that are physically and chemically very different.

In this study we aimed to evaluate the influence of the co-feeding period on the survival and growth of larvae of nishikigoi $C$. carpio, during the transition from living food to inert food and to determine the best time to stop feeding living food.

\section{MATERIALS AND METHODS}

The larvae of nishikigoi $C$. carpio were taken from three breeding pairs submitted to hormonal induction in the Aquaculture sector of IFES- Campus Alegre, using crude extract of carp hypophysis (WOYNAROVICH \& HORVÁTH, 1983). On the third day after hatching (3 DAH), the larvae were uniformized and transported to the Aquaculture Sector of Zootechnics and Animal Nutrition Laboratory at the Center for Agricultural Sciences and Technology, Universidade Estadual do Norte Fluminense - Darcy Ribeiro (LZNA/UENF), in Campos dos Goytacazes - RJ, where they were allowed to acclimatize to their new environment.

On the fourth day after hatching (4 DAH), it was observed that most of the larvae showed marked swimming activity in the horizontal direction. As this experiment required the use of only larvae that were able to consume exogenous food, it was necessary to identify larvae possessing the following characteristics: reduced yolk sac, open anus, and also those with mouth open and moving. Thus, nishikigoi larvae at $4 \mathrm{DAH}$, with the above characteristics were identified and used in the experiment. The initial weight of the larvae was $1.33 \pm 0.12 \mathrm{mg}$ and the total length was $6.0 \pm 0.33 \mathrm{~mm}$. Before starting the exogenous feeding, the larvae were distributed at a density of 7 individuals/L of water, making a total of 1,680 larvae used in the experiment.

A system of intensive hatchery was used, which was composed of 24 experimental units with a volume of $10 \mathrm{~L}$ each, with independent inlet and 
outlet of water, continuous circulation, mechanical and biological filter system, and temperature control by a heater equipped with a thermostat. The water flow was regulated to allow 20 renewals/day in the experimental units. Under these experimental conditions, six treatments were tested with four replications per treatment. A schematic representation of this is shown in figure 1.

Newly hatched Artemia nauplii (Artemia franciscana) were used as living food. The number of nauplii provided from the first to the sixth day was 150 nauplii/larvae/day. From the seventh day, this was increased to 300 nauplii/larvae/day. In the treatment that received only living food throughout the experimental period (LF), after the eighteenth day this was further increased to 600 nauplii/larvae/day. In co-feeding treatments, the amount of nauplii was gradually reduced over the last three days to $75 \%$, $50 \%$, and $25 \%$ of the total offered.

A commercial extruded ration that is sold in powder form was used as inert food. This is suitable for early stages of carnivores and omnivores tropical fish and contains the following: Protein (min.): $55.0 \%$; Ethereal Extract (min.): 10\%; Gross Fiber (ymax.): 5.0\%; Calcium (max.): $2.0 \%$; Phosphorus (min.): 1.0\%; Ash (max.): 10.0\%; Vitamin C: $500.0 \mathrm{mg}$. The inert food was provided ad libitum.

Larvae were fed three times a day, always at 8 a.m., 12 p.m., and 5 p.m. In treatments where there was co-feeding, the living food was provided first, and after about five minutes the inert food was provided. Artificial lighting was not adopted, and the larvae were exposed to the natural photoperiod with approximately 13 hours of light.

The water from the experimental units was siphoned out daily, at 2p.m., to remove the feces, uneaten food, and dead larvae. Mortality was recorded after the first feeding and during cleaning of the experimental units. In both cases the dead larvae were removed with the aid of a pipette.

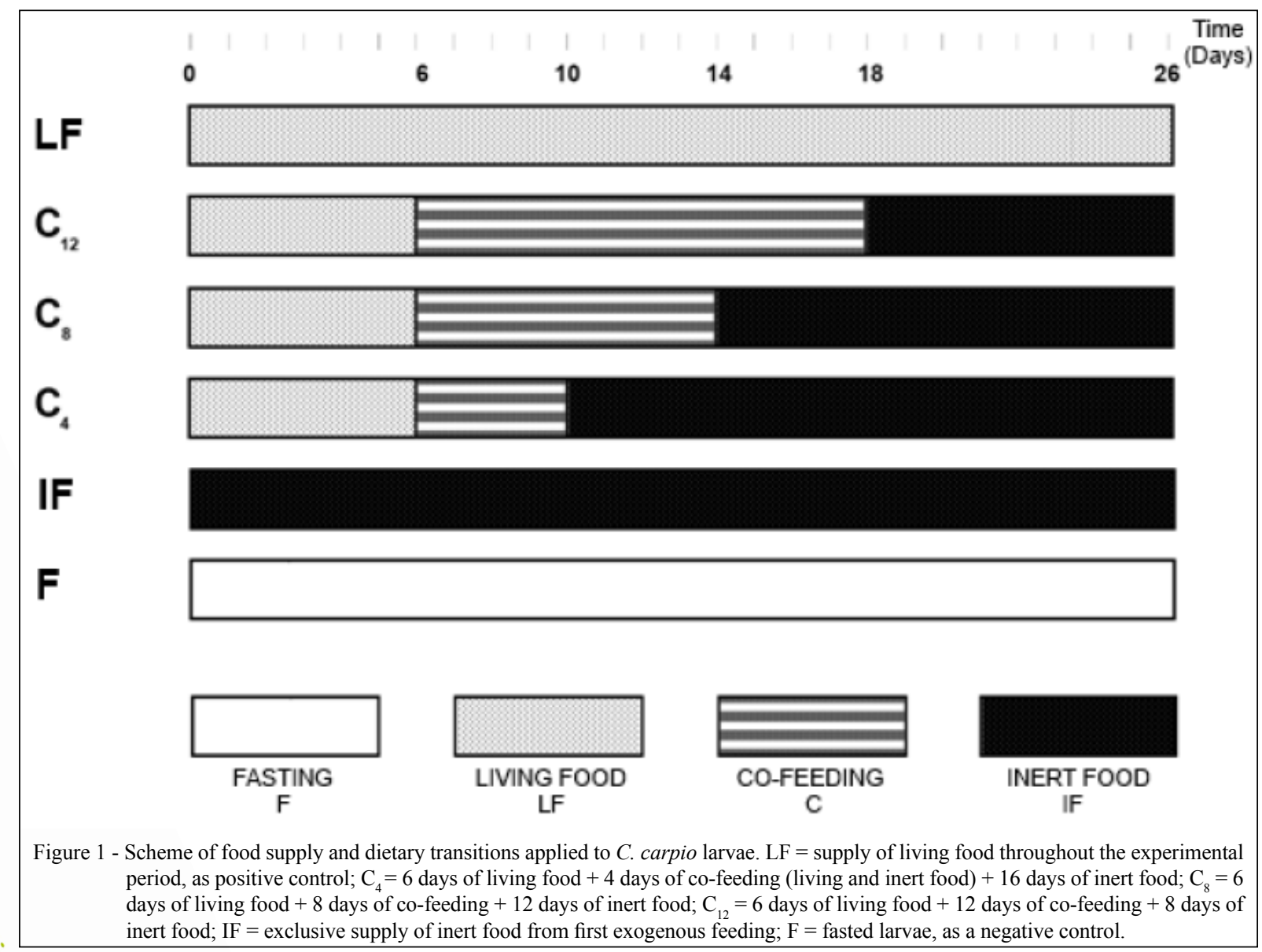

Ciência Rural, v.48, n.4, 2018. 
The monitoring of dissolved oxygen, temperature, and $\mathrm{pH}$ of water were performed daily at 9 a.m. The dissolved oxygen $(5.9 \pm$ $0.19 \mathrm{mg} / \mathrm{L})$ and temperature $\left(27.2 \pm 0.45{ }^{\circ} \mathrm{C}\right)$ were monitored with the aid of an oximeter, and the $\mathrm{pH}(6.8 \pm 0.14)$, with a $\mathrm{pH}$ meter, both digital and accurate to two decimal points. At the beginning and at the end of the experiment, the total ammonia was measured and the nonionized ammonia was calculated $(<0.001 \mathrm{mg} / \mathrm{L})$. The measured parameters remained within the recommended levels for the species (BOYD, 1990; GRAEFF \& PRUNER, 2000; PROENÇA \& BITTENCOURT, 1994).

To evaluate the growth and survival, an initial biometrics was performed followed by four intermediate biometrics ( $\mathrm{n}=5$ for each experimental unit larvae) at the beginning and end of each co-feeding period, and a last one at the end of the experiment $(n=10$ larvae for each experimental unit). In these larvae, total length and wet weight were measured. From the biometric data we calculated the following for each experimental unit: specific growth rate in weight (weight SGR) $=(\ln$ final weight $-\ln$ initial weight $) \times 100 /$ time interval (days), the specific growth rate in length $($ length SGR $)=(\ln$ final length $-\ln$ initial length $) \times$ 100/time interval (days) and survival (Final no. of larvae/(Initial no. of larvae - No. of larvae collected for biometrics) $\times 100$.

The data, presented as average \pm standard deviation, were subjected to parametric analysis of variance (ANOVA), considering the average results of each sampling unit. For results that showed significant differences between treatments, averages were compared using the Tukey test $(\mathrm{P}<0.05)$. Survival data and SGR in weight and length were transformed using the formula $\mathrm{y}=\operatorname{arc}$ sen $\sqrt{x} / 100$, where $x$ is the percentage survival. The independent variable "time providing Artemia" was analyzed by regression. All analyses were performed using the Statistical Analysis System, version 9.0 (SAS, 1995).

\section{RESULTS AND DISCUSSION}

Our results showed that survival at the end of the experiment (Figure 2 and Table 1) was influenced $(\mathrm{P}<0.05)$ by the dietary strategy adopted, ranging from $0 \%$ in larvae fed exclusively with the inert food (IF treatment), up to $96 \%$, in those that received only living food during the 26 days of larval rearing (LF treatment).
In the $\mathrm{R}$ treatment, immediately after the first supply of inert food, intake of particles by the larvae was observed. As this treatment provided greater life-span of larvae compared to those that were not fed at all (Treatment F), one can infer that the commercial diet contributed with some nutritional support to the larvae. This amount; however, was insufficient to sustain satisfactory growth (basal metabolism) of the larvae, causing death by starvation. Similarly, SOARES et al. (2000) reported a total mortality of larvae of cyprinid Carassius auratus when exclusively fed with commercial ration, containing $56 \%$ of crude protein, similar to that used in the present research. Similar results were obtained with pacu larvae, Piaractus mesopotamicus (TESSER et al., 2005) and beta Betta splendens, (FOSSE et al., 2013), fed exclusively on inert food since the beginning of exogenous feeding, culminating in total mortality or commercial impracticability of adopting this practice.

The main factors that cause failure in the supply of fish larvae that were fed exclusively with inert food include, low intake of diet, inadequate nutritional composition to ensure proper development of larvae, and immature digestive system to digest and assimilate the nutrients in the diet (MENOSSI et al., 2012). The influence of the quality of the inert food in the survival and growth of fish larvae have already been mentioned by JOMORI et al. (2008), who observed $11 \%$ survival of pacu larvae that were fed exclusively on specific commercial ration for fish larvae (Fry Feed Kiowa). It is noteworthy that dietary practices adopted can strongly influence the results, since LEITÃO et al. (2011), in an experiment with the same species of fish and the same diet, reported a total mortality of larvae that were exclusively fed with inert food.

Survival was influenced $(\mathrm{P}<0.05)$ by the duration of co-feeding, with a trend towards reduction in survival following the removal of living food, which was more pronounced when the period of co-feeding was shorter (Figure 2).

Survival of larvae subjected to $\mathrm{C}_{12}$ and $\mathrm{C}_{8}$ treatments was similar $(\mathrm{P}>0.05)$, and in both treatments their survival was higher $(\mathrm{P}<0.05)$ in comparison to the $\mathrm{C}_{4}$ treatment. When comparing the survival in treatments in which the larvae were co-fed with those in the LF treatment, it was reported that there was no significant difference between the LF and $\mathrm{C}_{12}$ treatments; although, the LF treatment was seen to be significantly superior to the $\mathrm{C}_{8}$ treatment.

Assuming that the LF treatment provided the best nutritional condition for larval survival, it is recommended that the $\mathrm{C}_{12}$ treatment protocol is adopted. These results are in agreement with the research of 


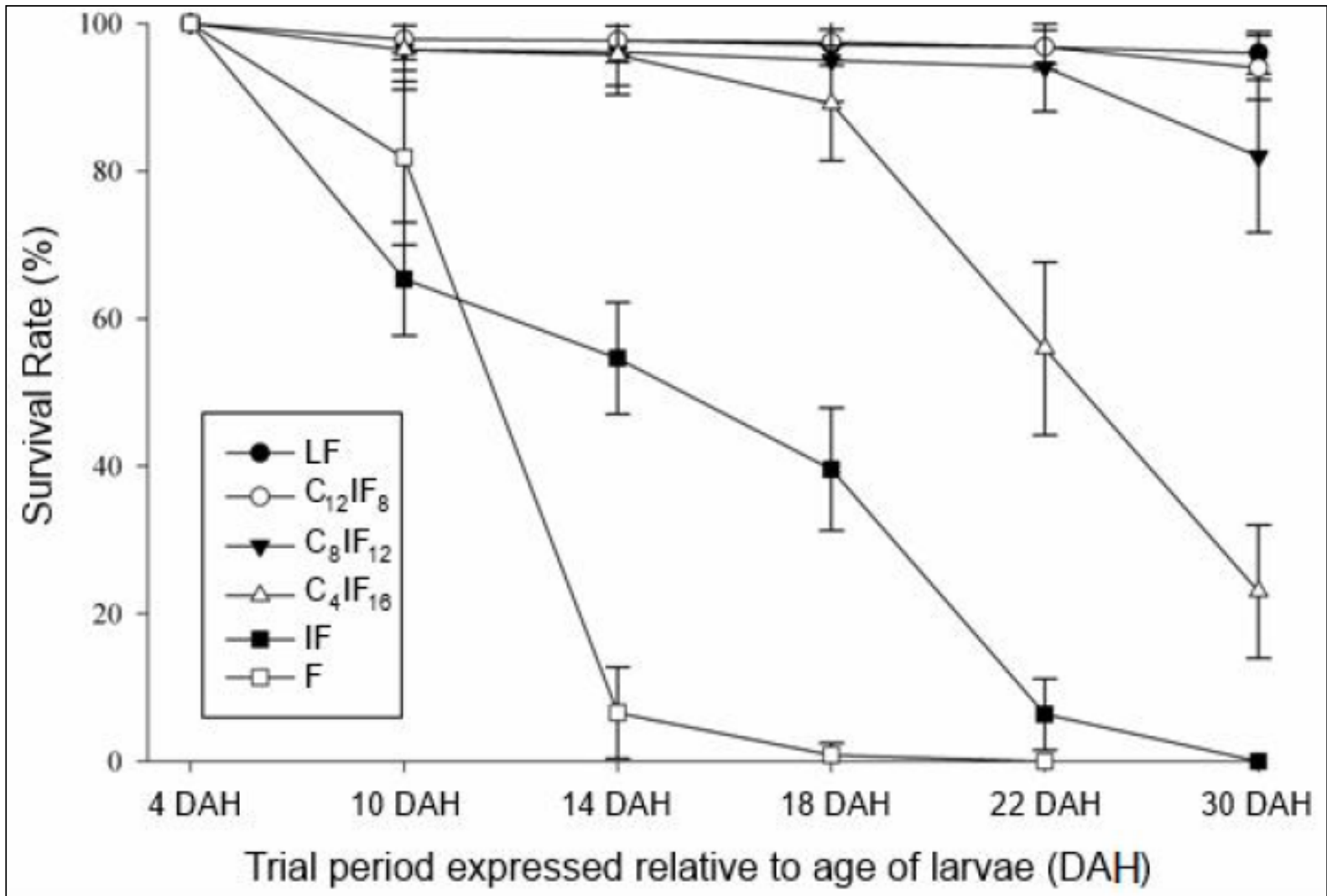

Figure 2 - Behavior of the survival of nishikigoi larvae C. carpio subjected to various diets over 26 days. DAH: Days after hatching.

DIEMER et al. (2010), FEIDEN et al. (2006), and SOARES et al. (2000) that have reported survival rates similar to those of longer co-feeding treatments.

The period of co-feeding reported an effect on growth of nishikigoi larvae over the 26 days of this experiment (Table 1). Larvae exposed to $\mathrm{C}_{12}$ treatment showed higher weight averages $(\mathrm{P}<0.05)$ than those of other treatments, including the larvae fed exclusively on living food, at $30 \mathrm{DAH}$. It can be inferred that cofeeding for a period of 12 days was sufficient duration for the larvae to be able to take advantages of the nutrients contained in the inert food, maximizing their growth by supplying a possible inadequate supply of nutrients to the larvae that were fed exclusively on living food. DIEMER (2010), FEIDEN (2006), and TESSER et al. (2005) also noted the possibility of obtaining growth rates, survival, and similar or greater weight, with the adoption of co-feeding, to those that used Artemia as the only source of food.

At $30 \mathrm{DAH}$, the weight of the larvae in the LF and $\mathrm{C}_{8}$ treatments did not differ $(\mathrm{P}>0.05)$ and both were higher than the $\mathrm{C}_{4}$ treatment, in which the early suppression of living food compromised the performance of the larvae. It was observed that the SGR in weight of larvae subjected to the $\mathrm{C}_{4}$ treatment in the period 4-10 DAH was similar $(\mathrm{P}>0.05)$ to the $\mathrm{LF}, \mathrm{C}_{12}$, and $\mathrm{C}_{8}$ treatments, when the larvae were still in co-feeding. After the removal of living food in $\mathrm{C}_{4}$ treatment, there was a significant reduction in the growth of the larvae. Although, the SGR in weight recovered during the periods of 18-22 DAH and 22-30 DAH, the larvae were not yet prepared to be fed exclusively on inert food, which significantly affected the survival and made the treatment impossible.

There was no significant difference in SGR in weight between LF, $\mathrm{C}_{12}$, and $\mathrm{C}_{8}$ treatments in all periods. These were the top three treatments that showed better results $(\mathrm{P}<0.05)$ than the $\mathrm{C}_{4}$ treatment, when considering the cumulative period (4-30 DAH).

Similar to results from this study, very early replacement of living food with inert food, have been reported to affect the growth and survival in pacu larvae (TESSER et al., 2005), and halibut (ROCHA et al., 2008). Considering the independent variable "time of supply of Artemia", we obtained the 
Table 1 - Nishikigoi carp growth performance exposed to different periods of co-feeding (average \pm standard-deviation).

\begin{tabular}{|c|c|c|c|c|c|c|}
\hline \multirow[b]{2}{*}{ Periods $^{*}$} & \multicolumn{6}{|c|}{ Treatments } \\
\hline & LF & $\mathrm{C}_{12}$ & $\mathrm{C}_{8}$ & $\mathrm{C}_{4}$ & IF & $\mathrm{F}$ \\
\hline \multicolumn{7}{|c|}{ } \\
\hline $10 \mathrm{DAH}$ & $7.52 \pm 0.65 \mathrm{~A}$ & $7.47 \pm 0.34 \mathrm{~A}$ & $8.04 \pm 0.83 \mathrm{~A}$ & $8.48 \pm 0.84 \mathrm{~A}$ & $3.01 \pm 0.15 \mathrm{~B}$ & $1.38 \pm 0.14 \mathrm{C}$ \\
\hline $14 \mathrm{DAH}$ & $23.01 \pm 1.33 \mathrm{~B}$ & $26.65 \pm 0.53 \mathrm{AB}$ & $28.61 \pm 3.49 \mathrm{~A}$ & $25.79 \pm 4.10 \mathrm{AB}$ & $4.66 \pm 0.25 \mathrm{C}$ & $1.82 \pm 0.26 \mathrm{C}$ \\
\hline $18 \mathrm{DAH}$ & $42.16 \pm 3.31 \mathrm{~B}$ & $56.42 \pm 6.98 \mathrm{~A}$ & $61.86 \pm 8.07 \mathrm{~A}$ & $39.53 \pm 2.87 \mathrm{~B}$ & $5.98 \pm 1.13 \mathrm{C}$ & - \\
\hline $22 \mathrm{DAH}$ & $76.56 \pm 5.39 \mathrm{AB}$ & $94.40 \pm 11.90 \mathrm{~A}$ & $85.33 \pm 18.67 \mathrm{~A}$ & $51.64 \pm 13.38 \mathrm{~B}$ & $12.24 \pm 3.30 \mathrm{C}$ & - \\
\hline $30 \mathrm{DAH}$ & $161.72 \pm 15.32 \mathrm{~B}$ & $192.07 \pm 12.82 \mathrm{~A}$ & $158.93 \pm 14.31 \mathrm{~B}$ & $87.67 \pm 12.93 \mathrm{C}$ & - & - \\
\hline \multicolumn{7}{|c|}{-1 } \\
\hline $10 \mathrm{DAH}$ & $9.50 \pm 0.42 \mathrm{~B}$ & $9.66 \pm 0.11 \mathrm{AB}$ & $10.21 \pm 0.23 \mathrm{~A}$ & $9.93 \pm 0.35 \mathrm{AB}$ & $7.97 \pm 0.27 \mathrm{C}$ & $6.96 \pm 0.20 \mathrm{D}$ \\
\hline $14 \mathrm{DAH}$ & $13.98 \pm 0.17 \mathrm{AB}$ & $14.15 \pm 0.31 \mathrm{AB}$ & $14.58 \pm 0.42 \mathrm{~A}$ & $13.58 \pm 0.32 \mathrm{~B}$ & $8.55 \pm 0.24 \mathrm{C}$ & $6.28 \pm 0.10 \mathrm{D}$ \\
\hline $18 \mathrm{DAH}$ & $15.92 \pm 0.56 \mathrm{AB}$ & $16.55 \pm 0.55 \mathrm{~A}$ & $16.55 \pm 0.46 \mathrm{~A}$ & $15.22 \pm 0.38 \mathrm{~B}$ & $8.81 \pm 0.34 \mathrm{C}$ & - \\
\hline $22 \mathrm{DAH}$ & $18.54 \pm 0.59 \mathrm{~A}$ & $19.20 \pm 0.51 \mathrm{~A}$ & $17.87 \pm 0.95 \mathrm{~A}$ & $15.52 \pm 1.32 \mathrm{~B}$ & $10.35 \pm 1.18 \mathrm{C}$ & - \\
\hline $30 \mathrm{DAH}$ & $23.63 \pm 0.93 \mathrm{~A}$ & $22.71 \pm 0.27 \mathrm{AB}$ & $21.50 \pm 0.60 \mathrm{~B}$ & $17.25 \pm 0.88 \mathrm{C}$ & - & - \\
\hline \multicolumn{7}{|c|}{ - } \\
\hline $10 \mathrm{DAH}$ & $97.86 \pm 1.84 \mathrm{~A}$ & $97.86 \pm 2.74 \mathrm{~A}$ & $96.43 \pm 5.41 \mathrm{~A}$ & $96.43 \pm 4.29 \mathrm{~A}$ & $65.36 \pm 7.68 \mathrm{~B}$ & $81.79 \pm 11.80 \mathrm{~B}$ \\
\hline $14 \mathrm{DAH}$ & $97.69 \pm 1.99 \mathrm{~A}$ & $97.69 \pm 2.95 \mathrm{~A}$ & $96.15 \pm 5.82 \mathrm{~A}$ & $95.77 \pm 4.24 \mathrm{~A}$ & $54.62 \pm 7.59 \mathrm{~B}$ & $6.54 \pm 6.20 \mathrm{C}$ \\
\hline $18 \mathrm{DAH}$ & $97.08 \pm 2.10 \mathrm{~A}$ & $97.5 \pm 3.19 \mathrm{~A}$ & $95.00 \pm 5.61 \mathrm{~A}$ & $89.17 \pm 7.76 \mathrm{~A}$ & $39.58 \pm 8.32 \mathrm{~B}$ & $0.83 \pm 1.67 \mathrm{C}$ \\
\hline $22 \mathrm{DAH}$ & $96.82 \pm 2.29 \mathrm{~A}$ & $96.82 \pm 3.11 \mathrm{~A}$ & $94.09 \pm 6.01 \mathrm{~A}$ & $55.91 \pm 11.72 \mathrm{~B}$ & $6.36 \pm 4.81 \mathrm{C}$ & $0.00 \pm 0.00 \mathrm{D}$ \\
\hline $30 \mathrm{DAH}$ & $96.00 \pm 2.83 \mathrm{~A}$ & $94.00 \pm 4.32 \mathrm{AB}$ & $82.00 \pm 10.33 \mathrm{~B}$ & $23.00 \pm 9.02 \mathrm{C}$ & $0.00 \pm 0.00 \mathrm{D}$ & $0.00 \pm 0.00 \mathrm{D}$ \\
\hline \multicolumn{7}{|c|}{ - } \\
\hline $04-10 \mathrm{DAH}$ & $28.86 \pm 1.42 \mathrm{~A}$ & $28.78 \pm 0.78 \mathrm{~A}$ & $29.94 \pm 1.75 \mathrm{~A}$ & $30.84 \pm 1.66 \mathrm{~A}$ & $13.60 \pm 0.80 \mathrm{~B}$ & $0.58 \pm 1.73 \mathrm{C}$ \\
\hline $10-14 \mathrm{DAH}$ & $27.99 \pm 1.41 \mathrm{~A}$ & $31.81 \pm 1.44 \mathrm{~A}$ & $31.71 \pm 3.96 \mathrm{~A}$ & $27.67 \pm 1.65 \mathrm{~B}$ & $10.96 \pm 1.12 \mathrm{~B}$ & $6.80 \pm 4.46 \mathrm{~B}$ \\
\hline $14-18 \mathrm{DAH}$ & $15.12 \pm 1.79 \mathrm{AB}$ & $18.61 \pm 3.14 \mathrm{AB}$ & $19.26 \pm 1.09 \mathrm{~A}$ & $10.87 \pm 4.17 \mathrm{BC}$ & $5.91 \pm 3.68 \mathrm{C}$ & - \\
\hline $18-22 \mathrm{DAH}$ & $14.93 \pm 0.95 \mathrm{~A}$ & $12.87 \pm 4.24 \mathrm{~A}$ & $7.78 \pm 2.66 \mathrm{~A}$ & $6.06 \pm 6.30 \mathrm{~A}$ & $17.54 \pm 7.79 \mathrm{~A}$ & - \\
\hline $22-30 \mathrm{DAH}$ & $9.33 \pm 0.81 \mathrm{~A}$ & $8.93 \pm 1.56 \mathrm{~A}$ & $7.94 \pm 1.89 \mathrm{~A}$ & $6.85 \pm 3.27 \mathrm{~A}$ & - & - \\
\hline 04 - $30 \mathrm{DAH}$ & $18.46 \pm 0.36 \mathrm{~A}$ & $19.13 \pm 0.25 \mathrm{~A}$ & $18.39 \pm 0.35 \mathrm{~A}$ & $16.09 \pm 0.57 \mathrm{~B}$ & - & - \\
\hline \multicolumn{7}{|c|}{ 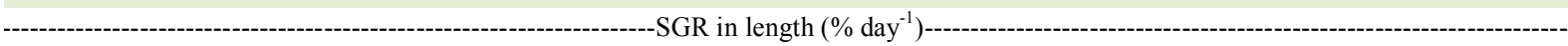 } \\
\hline 4 - 10 DAH & $7.64 \pm 0.75 \mathrm{~A}$ & $7.94 \pm 0.19 \mathrm{~A}$ & $8.86 \pm 0.38 \mathrm{~A}$ & $8.40 \pm 0.59 \mathrm{~A}$ & $4.73 \pm 0.56 \mathrm{~B}$ & $2.47 \pm 0.49 \mathrm{C}$ \\
\hline $10-14 \mathrm{DAH}$ & $9.69 \pm 0.98 \mathrm{~A}$ & $9.54 \pm 0.67 \mathrm{~A}$ & $8.89 \pm 0.83 \mathrm{~A}$ & $7.81 \pm 0.43 \mathrm{~A}$ & $1.74 \pm 1.26 \mathrm{~B}$ & $-2.57 \pm 0.55 \mathrm{C}$ \\
\hline $14-18 \mathrm{DAH}$ & $3.23 \pm 0.90 \mathrm{~A}$ & $3.90 \pm 1.04 \mathrm{~A}$ & $3.17 \pm 0.72 \mathrm{~A}$ & $2.86 \pm 1.07 \mathrm{AB}$ & $0, .76 \pm 1.46 \mathrm{~B}$ & - \\
\hline $18-22 \mathrm{DAH}$ & $3.81 \pm 0.75 \mathrm{~A}$ & $3.72 \pm 1.07 \mathrm{~A}$ & $1.90 \pm 0.68 \mathrm{AB}$ & $0.42 \pm 1.94 \mathrm{~B}$ & $3.91 \pm 2.63 \mathrm{~A}$ & - \\
\hline $22-30 \mathrm{DAH}$ & $3.03 \pm 0.23 \mathrm{~A}$ & $2.10 \pm 0.37 \mathrm{AB}$ & $2.33 \pm 0.76 \mathrm{AB}$ & $1.34 \pm 0.59 \mathrm{~B}$ & - & - \\
\hline 4 - 30 DAH & $5.27 \pm 0.15 \mathrm{~A}$ & $5.12 \pm 0.05 \mathrm{AB}$ & $4.91 \pm 0.11 \mathrm{~B}$ & $4.06 \pm 0.20 \mathrm{C}$ & - & - \\
\hline
\end{tabular}

Averages followed by the same letter (horizontally) do not differ by Tukey test $(\mathrm{P}<0.05)$. LF: living food throughout the experimental period, $\mathrm{C}_{12}=6$ days of living food +12 days of co-feeding +8 days of inert food, $\mathrm{C}_{8}=6$ days of living food +08 days of co-feeding +12 days of inert food; $\mathrm{C}_{4}=6$ days of living food +04 days of co-feeding +16 days of inert food; IF $=$ inert food (commercial ration) throughout the experimental period; $\mathrm{F}=$ fasting throughout the experimental period; DAH = Days after hatching. ${ }^{*}$ To the beginning of the experimental period, the larvae had 4 days after hatching (4 DAH).

regression equation for the variables analyzed. All dependent variables showed a quadratic effect, with maximum points ranging from 19 to 22 days of supply of living food (Figure 3).

\section{CONCLUSION}

Nishikigoi larvae are unable to take advantage of the inert food from the first exogenous feeding when this is the only source of food. The period of co-feeding influences the survival and the growth of nishikigoi carp larvae. After six days of living food, followed by 12 days of co-feeding, juveniles are able to consume only inert food without damage to their growth and survival, besides producing larvae with higher weight than larvae that were fed exclusively on living food. 

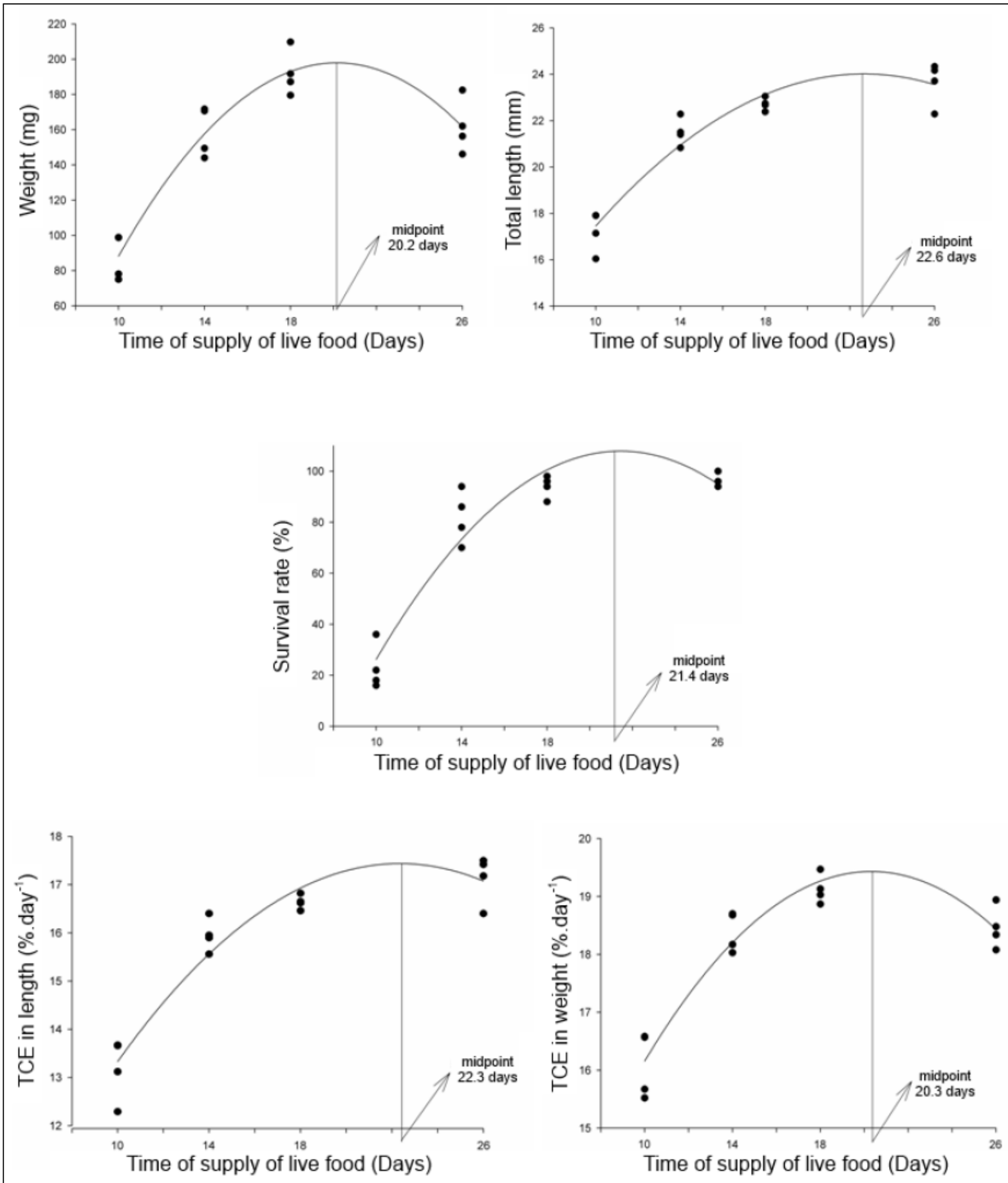

Figure 3 - The highest point for the performance variables of larvae C. carpio in relation to the number of days they were fed on living food.

\section{ACKNOWLEDGMENTS}

I thank the Instituto Federal de Educação, Ciência e Tecnologia do Espírito Santo (IFES-Campus Itapina) for the opportunity to attend the Postgraduate Program (Animal Science) at the Universidade Estadual do Norte Fluminense Darcy Ribeiro (UENF). We thank UENF for the support to execute this work. To IFES - Campus Alegre for the donation of the Cyprinus carpio larvae. 


\section{DECLARATION \\ OF \\ CONFLICTING INTERESTS}

Do not potential conflicts of interest with respect to the research, autorship, and/or publication of this article.

\section{REFERENCES}

BOYD, C.E. Water quality in ponds for aquaculture. Alabama: Fisheries and Allied Aquacultures Dept., Alabama Agricultural Experiment Station, Auburn University, 1990. 482p.

CAHU, C.; ZAMBONINO-INFANTE, J.L. Substitution of live food by formulated diets in marine fish larvae. Aquaculture, v.200, p.161-180, 2001. Available from: $<$ https://doi.org/10.1016/ S0044-8486(01)00699-8>. Accessed: Mar. 17, 2018. doi: 10.1016/ S0044-8486(01)00699-8.

DIEMER, O. et al. Manejo alimentar na larvicultura do mandi-pintado Pimelodus britskii. Revista Brasileira de Saúde e Produção Animal, v.11, n.3, p.903-908, 2010. Available from: <http://revistas.ufba.br/ index.php/rbspa/article/view/1715/1012>. Accessed: Mar. 17, 2018.

FEIDEN, A. et al. Desenvolvimento de larvas de surubim-doiguaçu Steindachneridion melanodermatum submetida a diferentes dietas. Revista Brasileira de Zootecnia, v.35, n.6, p.22032210, 2006. Available from: <http://dx.doi.org/10.1590/S151635982006000800002>. Accessed: Mar. 17, 2018. doi: 10.1590/ S1516-35982006000800002.

FOSSE, P.J. et al. Co-feeding strategy on survival and growth of Betta splendens larvae during weaning. Arquivo Brasileiro de Medicina Veterinária e Zootecnia, v.65, n.6 p.1801-1807, 2013. Available from: <http://dx.doi.org/10.1590/S0102 09352013000600030>. Accessed: Mar. 17, 2018. doi: 10.1590/ S0102-09352013000600030.

GRAEFF, A.; PRUNER, E.N. Effect of Population Density on the Productivity of Carp (Cyprinus carpio var specularis), in the Fattening Stage, During the Summer. Revista Brasileira de Zootecnia, v.29, n.3, p.639-645, 2000. Available from: <http:// www.scielo.br/pdf/rbz/v29n3/5804.pdf $>$. Accessed: Mar. 17, 2018.

HANIFFA, M.A. et al. Breeding behavior and embryonic development of koi carp (Cyprinus carpio). Taiwania, v.52, p.9399, 2007. Available from: <http://tai2.ntu.edu.tw/taiwania/pdf/ tai.2007.52.93.pdf $>$. Accessed: Mar. 17, 2018

JELKIĆ, D. et al. Rearing carp larvae (Cyprinus carpio) in closed recirculatory system (ras). Ribarstvo, v.70, p.9-17, 2012. Available from: <https://ribarstvo.agr.hr/volumes.php?lang=en\&search=Arti cle\%3A547>. Accessed: Mar. 17, 2018.

JOMORI, R.K. et al. Economic evaluation of Piaractus mesopotamicus juvenile production in different rearing systems. Aquaculture, v.243, n.1-4, p.175-183, 2005. Available from: $<$ https://doi.org/10.1016/j.aquaculture.2004.09.034>. Accessed: Mar. 17, 2018. doi: 10.1016/j.aquaculture.2004.09.034

JOMORI, R.K. et al. Stable carbon $(\delta 13 \mathrm{C})$ and nitrogen $(\delta 15 \mathrm{~N})$ isotopes as natural indicators of live and dry food in Piaractus mesopotamicus (Holmberg, 1887) larval tissue. Aquaculture Research, v.39, p.370-381, 2008. Available from: $<$ https://doi.or g/10.1111/j.1365-2109.2007.01760.x>. Accessed: Mar. 17, 2018. doi: $10.1111 /$ j.1365-2109.2007.01760.x.
JOMORI, R.K. et al. Growth and survival of pacu Piaractus mesopotamicus (Holmberg, 1887) juveniles reared in ponds or at different initial larviculture periods indoors. Aquaculture, v.221, p.277-287, 2003. Available from: <https://doi.org/10.1016/S00448486(03)00069-3>. Accessed: Mar. 17, 2018. doi: 10.1016/S00448486(03)00069-3.

KOLKOVSKI, S. Digestive enzymes in fish larvae and juveniles - implications and applications to formulated diets. Aquaculture, v.200, p.181-201, 2001. Available from: <https://doi.org/10.1016/ S0044-8486(01)00700-1>. Accessed: Mar. 17, 2018. doi: 10.1016/ S0044-8486(01)00700-1.

LEITÃO, N. et al. The influence of initial feeding on muscle development and growth in pacu Piaractus mesopotamicus larvae. Aquaculture, v.315, p.78-85, 2011. Available from: $<$ https://doi. org/10.1016/j.aquaculture.2011.01.006>. Accessed: Mar. 17, 2018. doi: 10.1016/j.aquaculture.2011.01.006.

LOMBARDI, D.C.; GOMES, L.C. Replacement of live food for inert food on larviculture of tambacu (q Colossoma macropomum X $\widehat{A}$ Piaractus mesopotamicus). Acta Scientiarum, Animal Sciences, v.30, p.467-472, 2008. Available from: $<$ https://doi. org/10.4025/actascianimsci.v30i4.3835>. Accessed: Mar. 17, 2018. doi: 10.4025/actascianimsci.v30i4.3835.

MENOSSI, O.C.C. et al. Growth and structure of the digestive system of pacu larvae fed microencapsulated diet produced experimentally. Rista Brasileira de Zootecnia, v.41, n.1, p.110, 2012. Available from: <http://dx.doi.org/10.1590/S151635982012000100001>. Accessed: Mar. 17, 2018. doi: 10.1590/ S1516-35982012000100001

PERSON LE RUYET, J. et al. Marine fish larvae feeding: formulated diets or live prey? Journal of the World Aquaculture Society, v.24, p.211-224, 1993. Available from: <https://doi. org/10.1111/j.1749-7345.1993.tb00010.x>. Accessed: Mar. 17, 2018. doi: 10.1111/j.1749-7345.1993.tb00010.x.

PORTELLA, M.C.; DABROWSKI, K. Diets, physiology, biochemistry and digestive tract development of freshwater fish larvae. In: CYRINO, J.E.P.; BUREAU, D.; KAPOOR, B.G. Feeding and Digestive Functions in Fishes. CRC Press, 2008. Chap. 6. p.227-279.

PORTELLA, M.C. et al. Alimentação e nutrição de larvas. In: FRACALOSSI, D. M; CYRINO, J.E. Nutriaqua: nutrição e alimentação de espécies de interesse para a aquicultura brasileira. Aquabio, 2013. Chap. 9. p.185-216.

PROENÇA, C.E.M.; BITTENCOURT, P.R.L. Manual de piscicultura tropical. Brasília: IBAMA, 1994. $196 \mathrm{p}$.

PUELLO-CRUZ, A. et al. Growth and survival of Siamese fighting fish, Betta Splendens, larvae at low salinity and with different diets. Journal of the World Aquaculture Society, v.41, p.823-828, 2010. Available from: <https://doi.org/10.11 11/j.1749-7345.2010.00425.x>. Accessed: Mar. 17, 2018. doi: 10.1111/j.1749-7345.2010.00425.x.

ROCHA, A.F. et al. Production of Brazilian flounder Paralichthys orbignyanus juveniles: the effect of co-feeding period during the weaning. Ciência Rural, v.38, n.8, p.23342338, 2008. Available from: <http://dx.doi.org/10.1590/S010384782008000800037>. Accessed: Mar. 17, 2018. doi: 10.1590/ S0103-84782008000800037. 
SOARES, C.M. et al. Plâncton, Artemia sp., dieta artificial e suas combinações no desenvolvimento e sobrevivência do kinguio Carassius auratus durante a larvicultura. Acta Scientiarum, v.22, p.383-388, 2000. Available from: <http://dx.doi.org/10.4025/ actascibiolsci.v22i0.2861>. Accessed: Mar. 17, 2018. doi: 10.4025/ actascibiolsci.v22i0.2861.

STATISTICAL ANALYSIS SYSTEMS - SAS. User's guide, version 6. 4 ed. Cary: 359 SAS $^{\circledR} /$ STAT, SAS Institute, 1995. 365p.

TESSER, M.B. et al. Co-feeding of pacu (Piaractus mesopotamicus, Holmberg, 1887) larvae with Artemia nauplii and microencapsulated. Journal of Applied Aquaculture, v.17, p.47-59, 2005. Available from: <https://doi.org/10.1300/J028v17n02_04>. Accessed: Mar. 17, 2018. doi: 10.1300/J028v17n02_04.

TESSER, M.B.; PORTELLA, M.C. Diet ingestion rate and pacu larvae behavior in response to chemical and visual stimuli. Revista Brasileira de Zootecnia, v.35, n.5, p.18871892, 2006. Available from: <http://dx.doi.org/10.1590/S151635982006000700002>. Accessed: Mar. 17, 2018. doi: 10.1590/ S1516-35982006000700002.

WOYNAROVICH, E.; HORVÁTH, L. A propagação artificial de peixes de águas tropicais: manual de extensão. Brasília: $\mathrm{FAO} /$ CODEVASF/CNPq, 1983. 